\title{
The Influence of Prematurity and Long Chain Polyunsaturate Supplementation in 4-Week Adjusted Age Baboon Neonate Brain and Related Tissues
}

\author{
ESZTER SARKADI-NAGY, VASUKI WIJENDRAN, GUAN-YEU DIAU, ANGELA CHUEH CHAO, \\ ANDREA T. HSIEH, ANU TURPEINEN, PETER W. NATHANIELSZ, AND J. THOMAS BRENNA \\ Division of Nutritional Sciences, Savage Hall [E.S.-N., V.W., G.Y.D., A.C.C., A.T.H., A.T., J.T.B.], and \\ Laboratory for Pregnancy and Newborn Research [P.W.N.], Cornell University, Ithaca, NY 14853, U.S.A.
}

\begin{abstract}
Clinical studies show that docosahexaenoic acid (DHA) and arachidonic acid (ARA) supplemented formula improve visual function in preterm infants, however improved fatty acid status is known only for plasma and red blood cells (RBC) since target organs cannot be sampled from humans. Baboons were randomized to one of four groups: Term breast-fed (B); Term formulafed $(\mathrm{T}-)$; Preterm formula-fed $(\mathrm{P}-)$; and Preterm DHA/ARAsupplemented formula-fed $(\mathrm{P}+)$. The $\mathrm{P}+$ contained $0.61 \pm$ $0.03 \%$ DHA and $1.21 \pm 0.09 \%$ ARA, and breast milk had 0.68 $\pm 0.22 \%$ and $0.62 \pm 0.12 \%$ as DHA and ARA, respectively. The $\mathrm{B}$ and $\mathrm{P}+$ groups had significantly higher DHA concentration in all tissues than $\mathrm{T}-$ and $\mathrm{P}-$. The $\mathrm{P}-$ group showed dramatically lower DHA content of $35 \%, 27 \%, 66 \%$, and $75 \%$ in the brain, retina, liver, and plasma, respectively, compared with B. Supplementation prevented declines in DHA levels in the retina, and liver, and attenuated the decline in brain, plasma and RBC of preterm animals. In contrast, ARA was not significantly lower compared with B in any group in any tissue but was significantly elevated in liver and brain. RBC and plasma DHA were correlated with DHA in tissues; RBC/plasma ARA were uncorrelated with tissue ARA. We conclude that 1) DHA drops precipitously in term and preterm primates consuming formula without long chain polyunsaturates, while $22: 5 n-6$ concentration rises; 2 ) tissue ARA levels are insensitive to dietary LCP supplementation
\end{abstract}

or prematurity, 3) plasma and RBC levels of ARA are uncorrelated with total ARA levels; 4) DHA levels are correlated with group effects and are uncorrelated within groups. (Pediatr Res 54: 244-252, 2003)

$\quad$ Abbreviations
ARA, arachidonic acid (20:4n-6)
B, breast-fed
CS, cesarean section
DHA, docosahexaenoic acid (22:6n-3)
EDTA, ethylenediaminetetraacetic acid
FA, fatty acid
FAME, fatty acid methyl ester
GC, gas chromatography
LA, linoleic acid (18:2n-6)
LCP, ( $\geq 20$ carbons) long-chain polyunsaturated fatty acids
LNA, $\alpha$-linolenic acid (18:3n-3)
PC, phosphatidylcholine
PE, phosphatidylethanolamine
PI, phosphatidylinositol
PL, phospholipids
PUFA, polyunsaturated fatty acid
RBC, red blood cells

Docosahexaenoic acid (DHA, 22:6n-3) is the major n-3 long chain polyunsaturated fatty acid (LCP) in the CNS of humans

\footnotetext{
Received October 8, 2002; accepted February 13, 2003.

Correspondence: J. Thomas Brenna, Cornell University, Savage Hall, Ithaca, NY 14853; e-mail: jtb4@cornell.edu

This work was supported by NIH grant EY10208.

Present address: Semmelweis University, Faculty of Medicine, Institute of Pathophysiology, Budapest, Hungary 1089 Nagyvarad ter 4 [E.S.-N.]; Foster Biomedical Laboratory, MS029 Brandeis University, P.O. Box 549110, Waltham, MA, 02454 U.S.A. [V.W.]; 325 Chen Con Road, Section 2, Division of Pediatric Surgery, Department of Surgery, Tri-Service General Hospital, National Defense Medical Center (NDMC), Nai-Whu, Taipei 10070, Taiwan ROC [G.Y.D.]; Department of Nutritional Sciences, University of Helsinki, Finland [A.T.]

DOI: 10.1203/01.PDR.0000072795.38990.F2
}

and nonhuman primates. DHA deficiency induced by severe dietary restriction of $n-3$ fatty acids has long been known to produce characteristic functional deficits, including impaired electroretinograms and visual-evoked potential responses, and poorer visual acuity (1). Very premature human infants were the first pediatric group for which DHA was hypothesized to be conditionally essential, largely because the beginning of accelerated brain growth at about $28 \mathrm{wk}$ gestation coincides with the conceptual birth age at which survival exceeds $50 \%$ (2). Early studies show that preterm infants consuming formulas containing DHA precursors but no DHA itself have poorer visual acuity than those who were supplemented with DHA (3-5). 
Concerns about overall growth raised by supplementation studies with DHA, as a component of high eicosapentaenoic acid (EPA) fish oil (6), led to the present consensus that arachidonic acid (ARA) should always be included with DHA supplementation (7). Formulas and baby foods supplemented with DHA/ ARA are now available in the USA and in many countries worldwide.

Since the early 1980s, at least 12 randomized clinical trials of LCP supplementation in premature human infants have appeared, testing effects of LCP supplementation on biochemical and/or functional outcomes of preterm infants, as well as the alternative strategy to alter the $n-6 / n-3$ precursor ratio to enhance DHA status (most reviewed recently by Gibson et al. (8)). Several showed improvements in visual development (9), consistent with findings from primate deficiency studies and the earliest human studies. Many studies have appeared for term infants as well, with rare exceptions showing either modest improvement or no differences. A major limitation to all these studies is that the target organs, specifically brain, retina, and liver, cannot be sampled in live human infants to assess how status changes with altered dietary intake. Red blood cells (RBC), and plasma phospholipid (PL) or total fatty acids (FA) are the usual proxies for organ concentrations, though buccal cell fatty acids obtained from cheek swab also respond to dietary fatty acid changes $(10-12)$. From these studies there is abundant evidence that the absence of dietary DHA/ARA results in significant decreases in blood cell and plasma DHA and ARA (13-17). These data are consistent with autopsy studies of sudden-infant-death syndrome infants showing that brain lipids of unsupplemented formula-fed infants have as much as a 40\% reduction in DHA compared with breast-fed infants, depending on brain region (18-21).

A convincing body of data shows that preterm infants suffer high rates of cognitive and behavioral deficits later in life (22-25). It is tempting to link these observations to the high CNS concentrations of DHA and ARA by the hypothesis that perinatal fatty acid nutrition limits ultimate neural development in preterms. Although preterms are capable of synthesizing DHA and ARA from their 18 carbon precursors $(26,27)$, the adequacy of the process to support the aggressive growth of the CNS is not known. There are no autopsy studies of tissue fatty acid composition to permit evaluation of DHA levels in premature infants with or without supplemented formula. Suitable animal models in controlled studies are required to establish whether human brain DHA and ARA concentrations are likely to be compromised in infants consuming formula containing only precursors. Baboons are among the most common models for prematurity, and as omnivorous primates are among the best models for human fatty acid nutrition (28), however there are no primate studies yet reported testing diets that manipulate n-3 fatty acid composition in diets of preterm primates.

The goal of this study was to determine the effect of prematurity and LCP supplementation on the fatty acid composition of brain, retina, liver, RBC, and plasma in neonatal baboons. Conceptual age matched randomized breast-fed and term groups served as controls. Correlations between ARA and DHA concentrations in plasma and erythrocytes versus those in developing tissues are examined to enable extrapolations in human studies.

\section{MATERIALS AND METHODS}

Animals and experimental design. All procedures involving animals were approved by the Cornell Institutional Animal Care and Use Committee (IACUC), and the animal facility is approved by the Association for Assessment and Accreditation of Laboratory Animal Care (AAALAC). The characteristics of the animals are summarized in Table 1. Twenty-two pregnant baboons/neonates were randomly assigned to one of four categories: term breast-fed (B) $(n=5)$; term formula-fed (T-; $n$ =7); preterm, formula-fed $(\mathrm{P}-; n=5)$; preterm, formula + LCP-fed $(\mathrm{P}+; n=5)$. Term and breast-fed animals were allowed to give birth spontaneously, around $182 \mathrm{~d}$ of gestational age. Formula-fed animals $(\mathrm{T}-)$ were transferred to nursery within $12 \mathrm{~h}$ of birth and fed a commercially available infant formula (Enfamil, Mead-Johnson, Evansville, IN, U.S.A.) without long-chain polyunsaturates (LCP) for $4 \mathrm{wk}$. There were two animals in the term group and one in the breast-fed group, which were kept for 6 wk. Their tissue fatty acid compositions were within the range defined by the 4-week animals and therefore all data were pooled. At about $151 \mathrm{~d}$ of gestation, females in the premature groups received two injections of antenatal betamethasone (175 mg/kg body weight/d) $48 \mathrm{~h}$ and $24 \mathrm{~h}$ before birth. Premature neonates were delivered by cesarean sections (CS) at $153 \pm 4 \mathrm{~d}$ of gestational age as estimated by ultrasound measurement of head circumference

Table 1. Animal Characteristics

\begin{tabular}{|c|c|c|c|c|}
\hline & B & $\mathrm{T}-$ & $\mathrm{P}-$ & $\mathrm{P}+$ \\
\hline Gender & $2 \mathrm{~F}, 3 \mathrm{M}$ & $5 \mathrm{~F}, 2 \mathrm{M}$ & $3 \mathrm{~F}, 2 \mathrm{M}$ & $3 \mathrm{~F}, 2 \mathrm{M}$ \\
\hline Gestational age at $\mathrm{CS}^{\mathrm{a}}(\mathrm{d})$ & Spontaneous labor & Spontaneous labor & $156 \pm 5$ & $154 \pm 2$ \\
\hline Age at euthanasia $(\mathrm{d})^{\mathrm{b}}$ & 28 & 28 & $208 \pm 2$ & $208 \pm 2$ \\
\hline Body weight at euthanasia $(\mathrm{g})^{\mathrm{c}}$ & $1152 \pm 177$ & $1147 \pm 113$ & $1071 \pm 187$ & $1035 \pm 220$ \\
\hline Brain weight at euthanasia $(\mathrm{g})^{\mathrm{c}}$ & $103 \pm 4$ & $98 \pm 6$ & $93 \pm 8$ & $94 \pm 9$ \\
\hline Liver weight at euthanasia $(\mathrm{g})^{\mathrm{c}}$ & $29 \pm 6$ & $35 \pm 4$ & $31 \pm 6$ & $29 \pm 6$ \\
\hline
\end{tabular}

Data are expressed as mean $\pm \mathrm{SD}$.

${ }^{a}$ CS, caesarean section.

${ }^{\mathrm{b}}$ Reported as birth age for $\mathrm{B}$ and $\mathrm{T}$ groups and conceptual (gestational) age for the $\mathrm{P}-$ and $\mathrm{P}+$ groups. The normal gestational period for baboons is $180-182$ days. Conceptual age for $\mathrm{B}$ and $\mathrm{T}$ at euthanasia was within 2 days of that for $\mathrm{P}-$ and $\mathrm{P}+$. Two animals in the $\mathrm{T}-$ group and one in the $\mathrm{B}$ group were 42 days old at euthanasia. Other than these, all animals were about 208 days post-conception at euthanasia.

${ }^{\mathrm{c}}$ Values that do not share common capital letter superscripts are significantly different $(p<0.05)$. 
and head biparietal diameter of the fetus (29). In two cases, a lung surfactant (Survanta ${ }^{\circledR}$, Ross Products Division, Abbott Laboratories, Columbus OH, U.S.A.) was administered to premature newborns because of mild respiratory distress. Five preterm neonates $(\mathrm{P}-)$ were fed a formula identical to the formula fed the $\mathrm{T}-$ group, and five received the LCPsupplemented formula $(\mathrm{P}+)$. All animals were fed six times a day, ad libitum, until they reached 4 wk adjusted age, corresponding to about $208 \mathrm{~d}$ since conception, when they were euthanized. The birth weight of premature neonates was significantly lower than that for term neonates, but at $4 \mathrm{wk}$ adjusted age ( $208 \mathrm{~d}$ postconception) there were no significant differences among body, brain, and liver weights of animals in the four groups.

Diets. The $\mathrm{P}-/ \mathrm{T}-$ formula was a commercially available preterm infant formula (Enfacare, Mead-Johnson, Evansville, IN, U.S.A.). The $\mathrm{P}+$ group was fed the same formula supplemented with microencapsulated ARA and DHA to provide $0.61 \pm 0.03 \%$ wt $(0.3 \%$ energy) DHA and $1.21 \pm 0.09 \%$ wt (0.6\% energy) ARA. Samples of breast milk were collected from lactating females on the day of neonate necropsy and analyzed for FA composition. Table 2 shows the FA composition of the different dietary regimes and the lactating female's chow. The breast milk and formula had similar linolenic acid (LNA, 18:3n-3) to linoleic acid (LA, 18:2n-6) ratios, the breast milk had about half the ARA, significantly more $22: 5 n-3$ and similar DHA concentrations compared with the $\mathrm{P}+$ formula. Eicosapentaenoic acid (EPA, 20:5n-3) was detected only in breast milk. Thin layer chromatography analysis verified that the ARA and DHA were in triglyceride form in the supplemented formula (data are not shown).

Sampling. Neonates were euthanized by exsanguination under halothane general anesthesia. Blood was drawn into EDTA-containing evacuated tubes, and RBC and plasma were separated by centrifugation. Liver and brain were removed quickly, weighed and placed individually in freezer bags. Both eyes were removed, and retinas were immediately dissected and stored in sterile saline. All samples were flash frozen and stored in liquid nitrogen until they were transferred to a $-80^{\circ} \mathrm{C}$ freezer, where they were maintained until analysis.

Analyses. Total lipids were extracted from the tissue homogenates and the diets according to a modified Bligh and
Dyer protocol $(30,31)$ using a chloroform-methanol-water 2:1:0.8 mixture with $0.02 \%$ butylated hydroxy toluene as an antioxidant. Fatty acid methyl esters (FAME) were formed by saponification using sodium hydroxide followed by esterification with boron-trifluoride $\left(\mathrm{BF}_{3}\right)$ in methanol. Freshly prepared di-heptadecanoyl-phosphatidylcholine for tissue samples or triheptadecanoin for diets (Matreya, Inc Pleasant Gap, PA, U.S.A.) was added as internal standard before homogenization. Total FAME were analyzed by gas chromatography (GC) (HP 5890 GC with flame ionization detector; BPX-70 capillary column: $60 \mathrm{~m} \times 0.32 \mathrm{~mm}$ ID $\times 0.25 \mu \mathrm{m}$ film thickness (SGE), using $\mathrm{H}_{2}$ carrier gas). FAME were identified by comparison with FAME standards, and the results were calibrated using response factors obtained from analysis of an equal weight FAME mixture of known composition using methyl heptadecanoate as an internal standard.

Statistics. Data are expressed as mean $\pm \mathrm{SD}$. A one-way ANOVA with unequal $n$ Tukey honest significant difference (HSD) post-hoc test was used to test for significant differences at $p<0.05$, performed by STATISTICA release 4.5 for Windows (StatSoft, Tulsa, OK, U.S.A.). Polynomial equations were fit to describe the change in \% FA of different organs with increasing plasma or RBC FA concentrations.

To evaluate whether correlations between plasma or RBC and tissue DHA (or ARA) were explained fully by group effects, the SPSS general linear model was used (Chicago, IL, U.S.A.). The model was $y=a x+z$, where $y$ is the organ DHA (or ARA), $a$ is the slope of $x, x$ is the either plasma or RBC DHA (or ARA) as covariate, and $z$ is the group as a categorical variable. If the slope of blood borne DHA $(a)$ is not significant after inclusion of the groups, then none of the remaining variation in the organ DHA (or ARA) is explained by the plasma or RBC DHA levels.

\section{RESULTS}

Visual cortex fatty acids. The visual cortex (brain) total FA composition is presented in Table 3, and the results for DHA and 22:5n-6/22:6n-3 (only) are shown graphically in Fig. 1. The B group had the highest brain DHA concentration while the $\mathrm{T}-$ and $\mathrm{P}-$ groups DHA concentrations were lower by $20 \%$ and $35 \%$, respectively. Supplementation supported simi-

Table 2. Fatty acid composition of maternal diet, breast milk, LCP-free formula and LCP supplemented formula as wt \% of total fatty acids (mean $\pm S D$ )

\begin{tabular}{|c|c|c|c|c|}
\hline Fatty Acids & Breast milk & $\begin{array}{l}\mathrm{T}-/ \mathrm{P}- \\
\text { Formula }\end{array}$ & $\mathrm{P}+$ Formula & $\begin{array}{c}\text { Female's } \\
\text { Feed }\end{array}$ \\
\hline$\Sigma$ SFA & $27.87 \pm 8.49$ & $30.22 \pm 2.66$ & $32.36 \pm 0.23$ & $30.37 \pm 0.66$ \\
\hline$\Sigma$ MUFA & $38.95 \pm 8.37$ & $44.72 \pm 2.18$ & $43.01 \pm 0.35$ & $35.27 \pm 0.99$ \\
\hline $18: 2 n-6$ & $27.23 \pm 3.99$ & $22.35 \pm 0.42$ & $20.11 \pm 0.14$ & $27.93 \pm 1.36$ \\
\hline $20: 4 n-6$ & $0.62 \pm 0.12$ & ND & $1.21 \pm 0.09$ & $0.24 \pm 0.04$ \\
\hline $22: 4 n-6$ & $0.22 \pm 0.06$ & ND & ND & ND \\
\hline $22: 5 n-3$ & $0.51 \pm 0.15$ & ND & $0.06 \pm 0.09$ & $0.20 \pm 0.03$ \\
\hline $22: 6 n-3$ & $0.68 \pm 0.22$ & ND & $0.61 \pm 0.03$ & $0.73 \pm 0.03$ \\
\hline $18: 2 n-6 / 18: 3 n-3$ & 12.84 & 9.59 & 9.76 & 10.83 \\
\hline
\end{tabular}

* ND, non-detectable. 
Table 3. Brain (visual cortex) fatty acid composition as wt\% of total fatty acids (mean $\pm S D$ )

\begin{tabular}{|c|c|c|c|c|}
\hline Fatty acid & $\mathrm{B}$ & $\mathrm{T}-$ & $\mathrm{P}-$ & $\mathrm{P}+$ \\
\hline$\Sigma$ SFA & $44.26 \pm 0.97^{\mathrm{a}}$ & $44.97 \pm 0.31^{\mathrm{ab}}$ & $45.14 \pm 0.61^{\mathrm{ab}}$ & $45.36 \pm 0.41^{\mathrm{b}}$ \\
\hline $18: 2 n-6$ & $1.25 \pm 0.13$ & $1.24 \pm 0.10$ & $1.25 \pm 0.15$ & $1.05 \pm 0.07$ \\
\hline $20: 4 n-6$ & $12.90 \pm 0.26^{\mathrm{a}}$ & $13.22 \pm 0.67^{\mathrm{a}}$ & $14.26 \pm 0.36^{\mathrm{b}}$ & $13.50 \pm 0.63^{\mathrm{ab}}$ \\
\hline $22: 5 n-6$ & $2.06 \pm 0.27^{\mathrm{ab}}$ & $2.46 \pm 0.45^{\mathrm{ab}}$ & $2.58 \pm 0.16^{\mathrm{a}}$ & $1.96 \pm 0.32^{\mathrm{b}}$ \\
\hline $24: 4 n-6$ & $0.16 \pm 0.02$ & $0.18 \pm 0.02$ & $0.19 \pm 0.02$ & $0.18 \pm 0.01$ \\
\hline$\sum \mathrm{n}-6$ & $23.85 \pm 0.76^{\mathrm{a}}$ & $25.32 \pm 1.10^{\mathrm{b}}$ & $27.20 \pm 0.26^{\mathrm{c}}$ & $24.37 \pm 0.73^{\mathrm{ab}}$ \\
\hline$\sum \mathrm{n}-3$ & $14.06 \pm 0.36^{\mathrm{a}}$ & $11.20 \pm 1.00^{\mathrm{b}}$ & $9.37 \pm 0.26^{\mathrm{c}}$ & $12.51 \pm 0.25^{\mathrm{d}}$ \\
\hline $22: 5 n-6 / 22: 6 n-3$ & $0.15 \pm 0.02^{\mathrm{a}}$ & $0.23 \pm 0.07^{\mathrm{bc}}$ & $0.29 \pm 0.02^{\mathrm{b}}$ & $0.16 \pm 0.03^{\mathrm{ac}}$ \\
\hline
\end{tabular}

Different superscripts in a row indicate significantly different values $(p<0.05)$.

¿SFA, sum of the saturated fatty acids; $\Sigma$ MUFA, sum of the monounsaturated fatty acids, were not significantly different among the groups and overall averaged $16.87 \pm 0.52 \%$ wt.
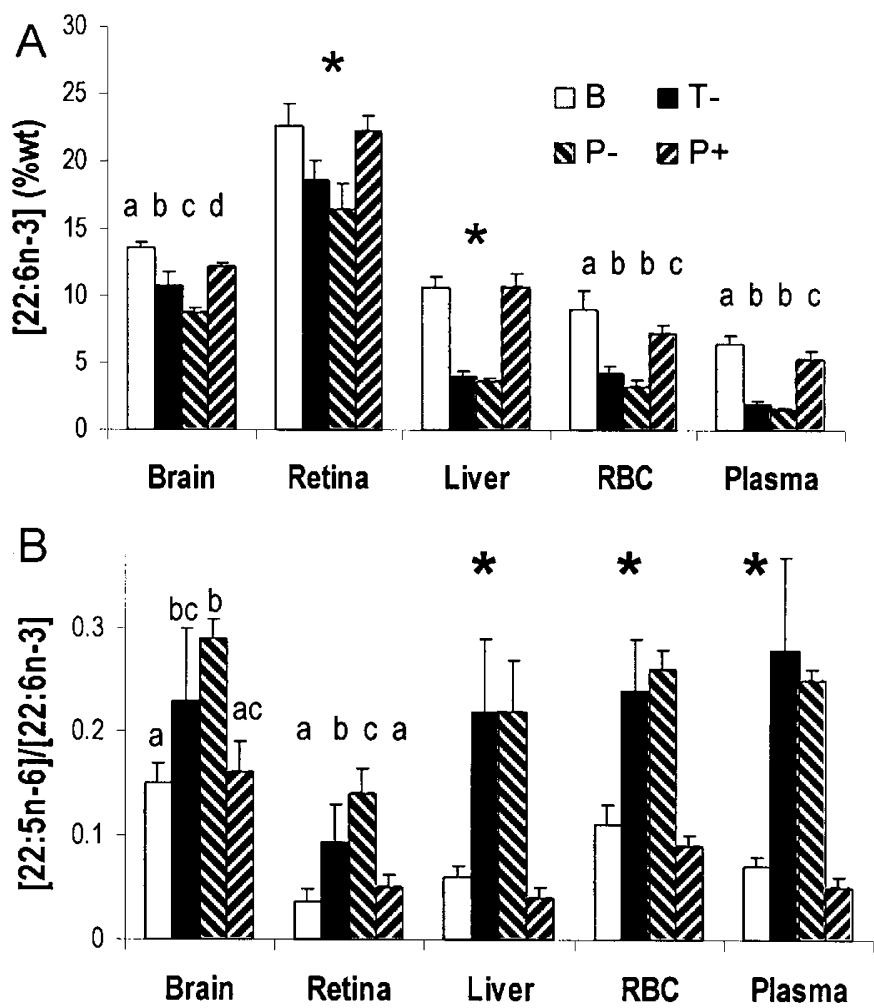

Figure 1. (A) DHA concentrations in brain, retina, liver, red blood cell $(\mathrm{RBC})$, and plasma. Different letters above bars indicate that groups have statistically different values $(p<0.05)$. In pools indicated by “*”, the treatments pair $\mathrm{B} / \mathrm{P}+$ and $\mathrm{T}-/ \mathrm{P}-$ are significantly different from one another $(p<$ $0.05)$, but not different within a pair. $(B)$ 22:5n-6/22:6n-3 ratio in the pools of $(A)$. Letters and "**" have the same meaning as in $(A)$.

lar concentrations in brain DHA as breast-feeding, though DHA in the $\mathrm{P}+$ group was $10 \%$ lower than that of the B group $(p<0.05)$. Figure $1 \mathrm{~b}$ illustrates the results for the 22:5n-6/ 22:6n-3 index, taken as an indicator of n-3 deficiency. Our results show that this index depended on the presence or absence of dietary DHA. The 22:5n-6/22:6n-3 ratios for the $\mathrm{T}-$ and $\mathrm{P}-$ groups were similar, as were the ratios for the $\mathrm{B}$ and $\mathrm{P}+$ groups; however, the 22:5n-6/22:6n-3 ratios of the Tand $\mathrm{P}-$ groups were elevated by 2 - to 5 -fold compared with those of the $\mathrm{B}$ and $\mathrm{P}+$ groups $(p<0.05)$.

In contrast to DHA results, a significantly greater ARA concentration was observed between the B group (12.9 \pm $0.3 \%)$ and the $\mathrm{P}-$ group $(14.3 \pm 0.4 \%)$, while the $\mathrm{T}-$ and $\mathrm{P}+$ group ARA levels were not significantly elevated relative to the B group ARA levels. Notable also is the effect of prematurity revealed by the significantly greater ARA concentration in $\mathrm{P}-$ compared with $\mathrm{T}-(13.2 \pm 0.7 \%)$.

Retina fatty acids. Our results for retina FAME analysis are summarized in Table 4. Group B had the highest DHA levels at $22.6 \pm 1.6 \%$, while both unsupplemented groups were significantly lower, at $18.6 \pm 1.4 \%$ for the $\mathrm{T}-$ group and 16.5 $\pm 1.8 \%$ for the $\mathrm{P}-$ group. Unlike in the brain, supplementation maintained the $\mathrm{P}+$ group retinal DHA concentrations (22.1 \pm $1.2 \%)$ at a level similar to that of the B group. The 22:5n-5/ 22:6n-6 ratio was similar for the $\mathrm{B}$ and $\mathrm{P}+$ groups, and was significantly elevated, by 2 - to 3 -fold, for the unsupplemented groups $(\mathrm{P}-, \mathrm{T}-)$.

All four groups had similar levels of retinal ARA. However, the elongation products of ARA, 22:4n-6 and 22:5n-6, were elevated in the unsupplemented formula groups compared with the B group.

Liver fatty acids. As shown in Table 5 and Fig. 1a, liver DHA concentration of the unsupplemented groups was dramatically depleted compared with the levels in the $\mathrm{B}$ and $\mathrm{P}+$ groups, which were not significantly different. The $\mathrm{T}-$ and $\mathrm{P}-$ groups had $37 \%$ and $34 \%$, respectively, of the liver DHA concentration in the B group, while the 22:5n-6/22:6n-3 index was elevated 3- to 4-fold compared with the $\mathrm{B}$ and $\mathrm{P}+$ groups. The EPA concentration was significantly elevated in the $B$ group, possibly due to the nonzero EPA levels in breast milk. Although all the neonate diets contained similar amounts of LNA, the breast-fed group had about double the liver LNA of the formula groups.

The livers of the B group had reduced levels of ARA compared with the other three groups, which could be explained by the presence of EPA in breast-milk but not in the neonate formulas. The $\mathrm{P}+$ group livers contained significantly less LA than the unsupplemented groups. Similarly, the unsupplemented groups showed elevated levels of 22:4n-6 and 22:5n-6.

RBC/plasma fatty acids. Quantitative FA profiles for RBC and plasma are presented in Tables 6 and 7, respectively. 
Table 4. Retina fatty acid composition as wt\% of total fatty acids (mean $\pm S D$ )

\begin{tabular}{|c|c|c|c|c|}
\hline Fatty acid & B & $\mathrm{T}-$ & $\mathrm{P}-$ & $\mathrm{P}+$ \\
\hline इMUFA & $14.61 \pm 0.95^{\mathrm{a}}$ & $16.51 \pm 0.99^{b}$ & $16.56 \pm 0.36^{\mathrm{b}}$ & $15.55 \pm 0.58^{\mathrm{ab}}$ \\
\hline $18: 2 n-6$ & $2.71 \pm 0.20^{\mathrm{ab}}$ & $2.81 \pm 0.30^{\mathrm{ab}}$ & $2.98 \pm 0.34^{\mathrm{a}}$ & $2.36 \pm 0.18^{\mathrm{b}}$ \\
\hline $20: 4 n-6$ & $10.39 \pm 0.43$ & $10.96 \pm 0.41$ & $11.11 \pm 0.82$ & $10.97 \pm 0.39$ \\
\hline $22: 5 n-6$ & $0.83 \pm 0.18^{\mathrm{a}}$ & $1.71 \pm 0.48^{\mathrm{bc}}$ & $2.28 \pm 0.37^{\mathrm{b}}$ & $1.10 \pm 0.24^{\mathrm{ac}}$ \\
\hline$\Sigma n-6$ & $17.90 \pm 0.82^{\mathrm{a}}$ & $20.53 \pm 1.18^{\mathrm{b}}$ & $21.70 \pm 1.09^{\mathrm{b}}$ & $18.82 \pm 0.30^{\mathrm{a}}$ \\
\hline $22: 5 n-3$ & $1.30 \pm 0.29^{\mathrm{a}}$ & $0.86 \pm 0.15^{\mathrm{b}}$ & $0.87 \pm 0.03^{\mathrm{b}}$ & $0.78 \pm 0.18^{\mathrm{b}}$ \\
\hline $22: 5 n-6 / 22: 6 n-3$ & $0.037 \pm 0.011^{\mathrm{a}}$ & $0.094 \pm 0.035^{\mathrm{b}}$ & $0.140 \pm 0.024^{\mathrm{c}}$ & $0.050 \pm 0.013^{\mathrm{a}}$ \\
\hline
\end{tabular}

Different superscripts in a row indicate significantly different values $(p<0.05)$.

$\Sigma$ SFA, sum of the saturated fatty acids, were not significantly different among the groups and overall averaged $43.0 \pm 1.2 \%$ wt; $\Sigma$ MUFA, sum of the monounsaturated fatty acids.

Table 5. Liver fatty acid composition as wt\% of total fatty acids (mean $\pm S D$ )

\begin{tabular}{|c|c|c|c|c|}
\hline Fatty acid & B & $\mathrm{T}-$ & $\mathrm{P}-$ & $\mathrm{P}+$ \\
\hline$\Sigma$ SFA & $41.31 \pm 1.67^{\mathrm{a}}$ & $38.03 \pm 1.95^{\mathrm{b}}$ & $38.61 \pm 1.77^{\mathrm{ab}}$ & $38.26 \pm 0.57^{\mathrm{b}}$ \\
\hline ¿MUFA & $10.83 \pm 0.96^{\mathrm{a}}$ & $16.20 \pm 2.20^{\mathrm{b}}$ & $16.11 \pm 1.74^{\mathrm{b}}$ & $15.33 \pm 2.11^{\mathrm{b}}$ \\
\hline $18: 2 n-6$ & $18.21 \pm 0.54^{\mathrm{a}}$ & $16.67 \pm 0.92^{\mathrm{a}}$ & $17.18 \pm 2.20^{\mathrm{a}}$ & $13.34 \pm 0.79^{b}$ \\
\hline $20: 4 n-6$ & $11.85 \pm 0.78^{\mathrm{a}}$ & $14.70 \pm 0.91^{\mathrm{b}}$ & $15.36 \pm 1.37^{\mathrm{bc}}$ & $17.16 \pm 1.24^{\mathrm{c}}$ \\
\hline $22: 4 n-6$ & $0.40 \pm 0.04^{\mathrm{a}}$ & $0.59 \pm 0.06^{\mathrm{bc}}$ & $0.66 \pm 0.08^{\mathrm{b}}$ & $0.54 \pm 0.06^{\mathrm{c}}$ \\
\hline $22: 5 n-6$ & $0.58 \pm 0.04^{\mathrm{ab}}$ & $0.86 \pm 0.29^{\mathrm{a}}$ & $0.76 \pm 0.13^{\mathrm{a}}$ & $0.38 \pm 0.11^{\mathrm{b}}$ \\
\hline$\Sigma n-6$ & $33.90 \pm 0.56^{\mathrm{a}}$ & $39.50 \pm 2.07^{\mathrm{b}}$ & $39.33 \pm 1.20^{\mathrm{b}}$ & $34.45 \pm 0.89^{\mathrm{a}}$ \\
\hline $20: 5 n-3$ & $0.36 \pm 0.13^{\mathrm{a}}$ & $0.19 \pm 0.04^{b}$ & $0.17 \pm 0.01^{\mathrm{b}}$ & $0.12 \pm 0.02^{b}$ \\
\hline $22: 5 n-3$ & $2.07 \pm 0.40^{\mathrm{a}}$ & $1.33 \pm 0.27^{\mathrm{b}}$ & $1.62 \pm 0.17^{\mathrm{ab}}$ & $0.67 \pm 0.08^{\mathrm{c}}$ \\
\hline $22: 6 n-3$ & $10.63 \pm 0.79^{\mathrm{a}}$ & $3.98 \pm 0.41^{\mathrm{b}}$ & $3.57 \pm 0.32^{\mathrm{b}}$ & $10.62 \pm 1.01^{\mathrm{a}}$ \\
\hline$\Sigma n-3$ & $13.25 \pm 0.88^{\mathrm{a}}$ & $5.66 \pm 0.33^{b}$ & $5.38 \pm 0.24^{\mathrm{b}}$ & $11.58 \pm 1.02^{\mathrm{c}}$ \\
\hline $22: 5 n-6 / 22: 6 n-3$ & $0.06 \pm 0.01^{\mathrm{a}}$ & $0.22 \pm 0.07^{\mathrm{b}}$ & $0.22 \pm 0.05^{\mathrm{b}}$ & $0.04 \pm 0.01^{\mathrm{a}}$ \\
\hline
\end{tabular}

Different superscripts in a row indicate significantly different values $(p<0.05)$.

¿SFA, sum of the saturated fatty acids; $\Sigma$ MUFA, sum of the monounsaturated fatty acids.

Table 6. Red blood cell (RBC) fatty acid composition as wt\% of total fatty acids (mean \pm SD)

\begin{tabular}{|c|c|c|c|c|}
\hline Fatty acid & B & $\mathrm{T}-$ & $\mathrm{P}-$ & $\mathrm{P}+$ \\
\hline ¿MUFA & $12.57 \pm 1.45^{\mathrm{a}}$ & $17.35 \pm 1.83^{b}$ & $19.04 \pm 1.46^{\mathrm{b}}$ & $17.03 \pm 0.90^{\mathrm{b}}$ \\
\hline $18: 2 n-6$ & $13.78 \pm 1.72^{\mathrm{a}}$ & $13.77 \pm 1.79^{\mathrm{a}}$ & $14.81 \pm 1.78^{\mathrm{a}}$ & $9.97 \pm 0.59^{\mathrm{b}}$ \\
\hline $20: 4 n-6$ & $18.19 \pm 2.54^{\mathrm{ab}}$ & $17.25 \pm 1.47^{\mathrm{a}}$ & $18.51 \pm 1.85^{\mathrm{ab}}$ & $21.20 \pm 0.54^{\mathrm{b}}$ \\
\hline $22: 5 n-6$ & $1.00 \pm 0.11^{\mathrm{a}}$ & $1.02 \pm 0.22^{\mathrm{a}}$ & $0.83 \pm 0.11^{\mathrm{ab}}$ & $0.65 \pm 0.07^{\mathrm{b}}$ \\
\hline$\Sigma n-6$ & $37.62 \pm 3.90^{\mathrm{ab}}$ & $38.30 \pm 1.18^{\mathrm{ab}}$ & $40.13 \pm 1.68^{\mathrm{a}}$ & $36.28 \pm 0.75^{b}$ \\
\hline $18: 3 n-3$ & $0.24 \pm 0.02$ & $0.32 \pm 0.07$ & $0.27 \pm 0.06$ & $0.20 \pm 0.04$ \\
\hline $22: 6 n-3$ & $8.92 \pm 1.48^{\mathrm{a}}$ & $4.26 \pm 0.43^{b}$ & $3.17 \pm 0.59^{b}$ & $7.15 \pm 0.72^{\mathrm{c}}$ \\
\hline$\sum n-3$ & $12.53 \pm 1.31^{\mathrm{a}}$ & $6.53 \pm 0.70^{b}$ & $5.56 \pm 0.64^{\mathrm{b}}$ & $8.48 \pm 0.89^{c}$ \\
\hline $22: 5 n-6 / 22: 6 n-3$ & $0.11 \pm 0.02^{\mathrm{a}}$ & $0.24 \pm 0.05^{\mathrm{b}}$ & $0.26 \pm 0.02^{\mathrm{b}}$ & $0.09 \pm 0.01^{\mathrm{a}}$ \\
\hline
\end{tabular}

Different superscripts in a row indicate significantly different values $(p<0.05)$.

$\Sigma$ SFA, sum of the saturated fatty acids, were not significantly different among the groups and overall averaged $36.2 \pm 2.8 \%$ wt.; $\Sigma$ MUFA, sum of the monounsaturated fatty acids.

Comparisons between the liver and plasma FA compositions show several similarities consistent with the role of the liver as an important site of LCP synthesis. As expected, the P+ group had higher levels of DHA in the RBC and plasma than did the $\mathrm{P}-$ group. Similar to the brain results, DHA levels in the plasma and $\mathrm{RBC}$ of the $\mathrm{P}+$ group were significantly lower than that of the $\mathrm{B}$ group. Plasma DHA in the $\mathrm{T}-$ and $\mathrm{P}-$ groups was further depressed, at levels $70 \%$ and $75 \%$ below the B group values, respectively. Plasma 22:5n-6/22:6n-3 indexes were similar to that of the liver, but the $\mathrm{T}-$ and $\mathrm{P}-$ groups were elevated by 4 - to 5 -fold compared with the $\mathrm{B}$ and $\mathrm{P}+$ groups.

Similar to the results for other tissues, plasma and RBC LA concentrations were significantly lower in the $\mathrm{P}+$ group whereas LNA levels did not show any significant differences. Significantly higher ARA levels found in the $\mathrm{P}+$ group plasma probably reflect the high dietary intake compared with the $\mathrm{B}$ group. However, it is notable that $\mathrm{B}, \mathrm{T}-$, and $\mathrm{P}-$ groups were 
Table 7. Plasma fatty acid composition as wt\% of total fatty acids (mean \pm SD)

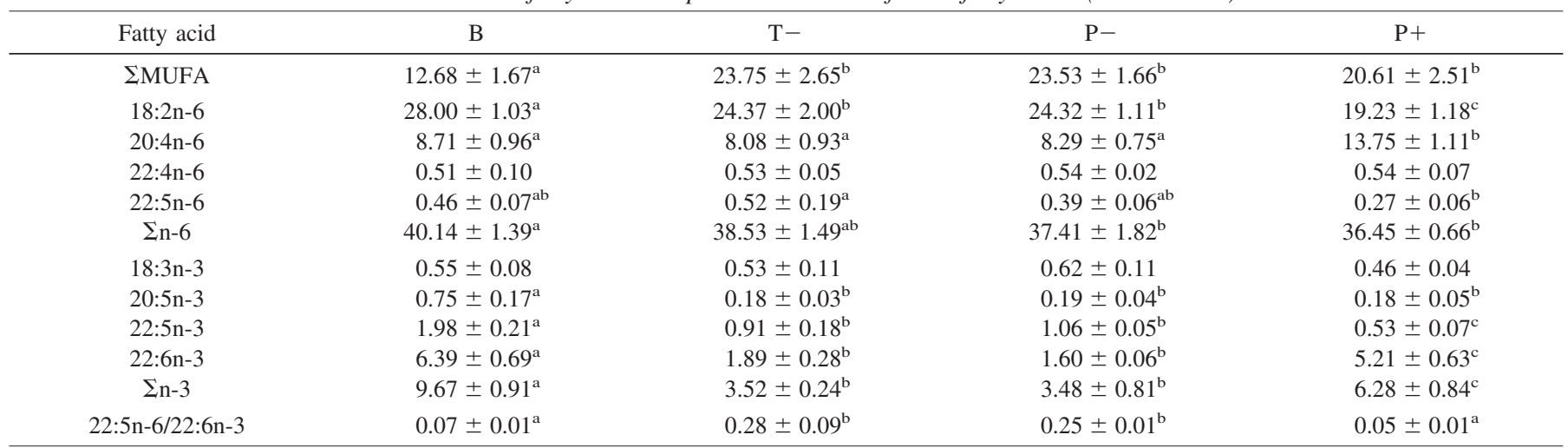

Different superscripts in a row indicate significantly different values $(p<0.05)$.

¿SFA, sum of the saturated fatty acids, were not significantly different among the groups and overall averaged $35.2 \pm 1.7 \%$ wt.; $\Sigma$ MUFA, sum of the monounsaturated fatty acids.

similar in plasma ARA concentrations despite the presence of ARA in breast milk but not in the unsupplemented formula groups. Unlike in the other tissues, 22:4n-6 in plasma and RBC did not change, and there was a modest trend in 22:5n-6 levels favoring the term groups $(\mathrm{B}, \mathrm{T}-)$.

Regression analysis. Neither the plasma nor the RBC ARA levels were correlated with the ARA levels of the other tissues. Figure $2 C$ shows the relationships between liver DHA versus $\mathrm{RBC}$ or plasma DHA, and the corresponding best-fit equations. The unsupplemented groups are clearly separated from B and $\mathrm{P}+$, consistent with the role of the liver as a storage site for LCP. Figs. $2 A$ and $B$ present the linear and quadratic relationships between DHA levels in brain and retina versus plasma or RBC. After group effects were included in the regression model, further analysis showed that no remaining variability in tissue DHA could be explained by RBC or plasma levels.

\section{DISCUSSION}

To isolate the effects of prematurity on neonates maintained on an unsupplemented diet, we directly compare the $\mathrm{P}-$ and $\mathrm{T}$ - groups since they were on identical diets and differed only in gestational age. Brain DHA was $18 \%$ lower in the $\mathrm{P}-$ group compared with the $\mathrm{T}-$ group $(p<0.05)$, and a similar, nonsignificant trend was consistently found in other pools. The 22:5n-6/22:6n-3 ratio was significantly elevated in retina but not in brain or in the other tissues. These results likely reflect the longer period that the $\mathrm{P}-$ group was without the benefit of maternally derived DHA via placental transfer. In contrast, brain ARA concentrations were significantly greater in the $\mathrm{P}-$ group compared with the $\mathrm{T}-$ group, and again, a similar, nonsignificant trend is evident for the other tissues. The importance of this seemingly paradoxical increase in ARA in prematurity is not apparent, nor is the reason for an increase in ARA products.

The effects of supplementation on FA composition can be evaluated by comparisons between the $\mathrm{P}+$ and $\mathrm{P}-$ groups, and secondarily the $\mathrm{B}$ versus $\mathrm{T}-$ groups. All pools showed greater DHA concentrations when DHA was present in the diet. In contrast, supplementation did not significantly influence ARA levels in most tissues, though plasma ARA in the P- group was less than that in the $\mathrm{P}+$ group, and in the $\mathrm{T}-$ livers ARA levels were greater than in the $\mathrm{B}$ livers. Comparing the brain data of the premature groups ( $\mathrm{P}-$ versus $\mathrm{P}+$ ), the ARA product 22:5n-6 decreased with supplementation. The $\mathrm{B}$ and $\mathrm{T}-$ groups did not show significant changes in this FA, but the sum of n- 6 fatty acids was significantly different as result of the trend in favor of the T- group. Overall, we conclude that DHA supplementation is effective at improving tissue DHA concentrations in premature baboons, but that ARA concentrations are more tightly controlled.

In the absence of dietary LCP, liver DHA levels were lower by $63 \%$ and $66 \%$ ( $\mathrm{T}-$ and $\mathrm{P}-$, respectively), plasma DHA was lower by $70 \%$ and $75 \%$, RBC DHA was lower by $52 \%$ and $64 \%$, but brain DHA was lower by only $21 \%$ and $35 \%$ compared with the B group. Assuming there are no significant differences in the concentrations of DHA among the groups at birth, these values represent decreases in DHA concentration in unsupplemented groups compared with the breast-fed group. These declines occurred even though the $\mathrm{T}-/ \mathrm{P}-$ formula contained LNA levels found in conventional formulas. The dramatic decreases in liver DHA concentrations and in blood pools (plasma and RBC) suggest that the liver capacity for LCP synthesis is limited. The smaller decrease observed in the visual cortex of the $\mathrm{T}-$ and $\mathrm{P}-$ groups is consistent with rapid uptake of LCP by the developing brain, which is spared the decrease in DHA seen in other tissues. Brain requirements appear to deplete plasma DHA and, in turn, decrease DHA levels in liver and other tissues. This conclusion is supported by evidence that brain LCP accretion requires mobilization of LCP from other organs (32).

The 22:5n-6/22:6n-3 ratio in tissues or blood is commonly used as an indicator of n-3 fatty acid deficiency, based in part on empirical observations showing that this ratio rises in $\mathrm{n}-3$ fatty acid deficiency. This phenomenon has been observed in preterm infants on formulas with varying amounts of $n-3$ fatty acids (13). It is thought that $22: 5 n-6$ is a structural analogue to DHA and can serve similar biochemical functions, though functional deficits suggest that $22: 5 n-6$ is not a fully effective replacement for DHA (33). In the present study, all tissues from the unsupplemented groups showed significantly elevated 

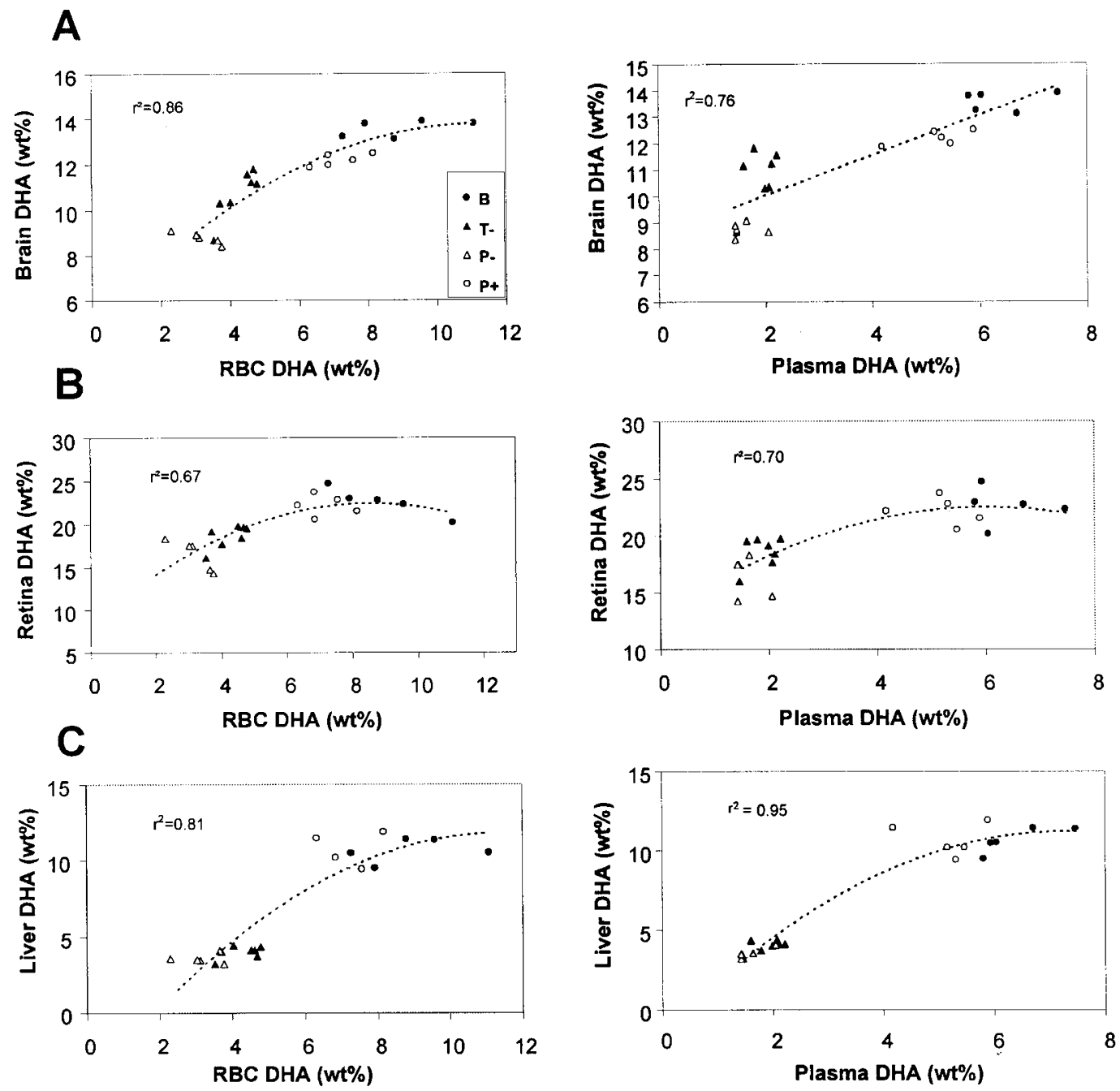

Figure 2. Legends for all panels are the same as shown in the first plot. (A) Brain DHA correlations to RBC and plasma DHA expressed as weight\%, with each point representing one animal. The least squares equations are: $\mathrm{Brain}_{\mathrm{DHA}}=-0.070 \mathrm{RBC}_{\mathrm{DHA}}{ }^{2}+1.6 \mathrm{RBC}_{\mathrm{DHA}}+4.9\left(\mathrm{r}^{2}=0.86\right)$ and $\mathrm{Brain}$ DHA $=0.75$ Plasma $_{\text {DHA }}+8.5\left(\mathrm{r}^{2}=0.76\right)$. (B) Retina DHA correlations to RBC and plasma DHA expressed as weight\%, with each point representing one animal. The least squares equations are: Retina $\mathrm{DHA}_{\mathrm{DHA}}=-0.19 \mathrm{RBC}_{\mathrm{DHA}}{ }^{2}+3.3 \mathrm{RBC}_{\mathrm{DHA}}+8.3\left(\mathrm{r}^{2}=0.67\right)$ and Retina $\mathrm{DHA}_{\mathrm{D}}=-0.26 \mathrm{Plasma}_{\mathrm{DHA}}{ }^{2}+3.2 \mathrm{Plasma}_{\mathrm{DHA}}+12.9\left(\mathrm{r}^{2}=\right.$ 0.70). (C) Liver DHA correlations to RBC and plasma DHA expressed as weight\%, with each point representing one animal. The least squares equations are: Liver $_{\mathrm{DHA}}=-0.13 \mathrm{RBC}_{\mathrm{DHA}}{ }^{2}+3.0 \mathrm{RBC}_{\mathrm{DHA}}-5.1\left(\mathrm{r}^{2}=0.85\right)$ and Liver $_{\mathrm{DHA}}=-0.24$ Plasma $_{\mathrm{DHA}}{ }^{2}+3.5$ Plasma $_{\mathrm{DHA}}-1.5\left(\mathrm{r}^{2}=0.95\right)$

22:5n-6/22:6n-3, with plasma and RBC being particularly high. This indicates that plasma and RBC should be sensitive probes of tissue 22:5n-6/22:6n-3 ratios, and our data are direct evidence that the plasma and $\mathrm{RBC}$ are markers for increases in this ratio in liver, brain and retina.

The large decreases in plasma and RBC DHA concentrations observed in our data are even greater than those reported in the most similar of the existing human preterm studies. Plasma DHA levels were lower by about $61 \%$ in preterms (2- and 6-wk-old) fed a formula with no DHA compared with a formula supplemented with $0.76 \%$ wt DHA, and by about $50 \%$ compared with a breast-fed reference group (14). Plasma DHA levels dropped $51 \%$ in 6 week old preterm infants fed an unsupplemented soy-oil-based diet compared with a supplemented diet (13), and by about $25 \mathrm{wk}$ of age the decrease was $59 \%$ (34). In those 6-week-old preterms, total RBC DHA was lower by $24 \%$ in a soy diet compared with a DHA supplemented diet (13). In another study, RBC DHA was lower by
$41 \%$ at 7 wk in DHA supplemented preterms compared with controls (35). Variability in total body fat at birth is one plausible factor that may contribute to the relatively wide range of plasma and RBC DHA decreases reported in human studies, as well as the generally milder decreases in humans compared with baboons. The human infant accumulates uniquely large body fat stores before birth $(36,37)$, and these stores contain significant amounts of DHA (38). Although preterm infants have much less body fat than term infants, the preterms in the cited studies averaged more than 30 wk gestational age, when the period of body fat accumulation is underway.

The unsupplemented group brain DHA concentrations were $34 \%$ to $37 \%$ lower than the B group, which is within the low end of the range reported in human autopsy studies. Those data showed decreases of $10 \%$ to $40 \%$ in brain DHA levels in unsupplemented formula-fed human infants, compared with breast-fed infants (18-21). Statistically valid comparisons between breast-fed and formula-fed infants are not possible in 
human studies because randomization is not possible. However, our results showing larger changes in plasma and RBC in baboons, leading to changes in brain DHA that are within the low end of human autopsy results, are consistent with the human data. If, indeed, preterm baboons have lower stores of DHA at birth than preterm humans, and if the primate brain is protected against low DHA at the expense of other organs, then plasma, RBC, and liver DHA depletion should lead to brain depletion, as we observe.

There are no animal data available, in any species, with which to compare our data on the effects of supplementation on prematurity. There are many studies of LCP supplementation in sub-primates, and our data are in good qualitative agreement with them. They generally show that most tissues increase DHA concentration in response to supplementation, while for ARA only plasma and RBC respond to supplementation. After 12 wk of feeding formula supplemented with ARA/DHA $(0.9 \% \mathrm{wt} / 0.6 \% \mathrm{wt})$ to guinea pigs, Abedin and coworkers found that the DHA tissue proportions improved by 1.4-fold in brain phosphatidylethanolamine (PE), 1.8-fold in retinal PL, and by 14-fold in the liver. We found 1.4-fold, 1.3-fold, and 3-fold increases in brain, retina, and liver DHA respectively with similar levels of supplementation. There were no changes in brain or retina ARA proportions even at the highest level of supplementation, however liver ARA was significantly elevated compared with controls (39). These data are in accord with our observations that ARA and DHA supplementation in the $\mathrm{P}+$ group did not increase retina and brain ARA levels compared with the $\mathrm{T}-$ and $\mathrm{P}-$ groups, while liver ARA increased significantly compared with the $\mathrm{T}-$ group only.

Piglets fed formula containing $0.5 \%$ wt ARA and $0.4 \%$ wt DHA showed greater tissue DHA levels compared with unsupplemented controls, with the most pronounced changes observed in liver and plasma ( $>2$-fold greater), while the retina and brain PE showed a modest 1.1-fold increase. ARA levels in plasma and RBC PE were greater, but were not different in brain and retina PE in comparison to no-LCP controls $(40,41)$. In our study, ARA and DHA provided at $1.21 \%$ wt and $0.61 \% \mathrm{wt}$, respectively, to the $\mathrm{P}+$ group resulted in elevated ARA only in plasma and not in the other tissues when compared with the $\mathrm{P}-$ group. In another piglet study, inclusion of ARA and DHA in the diet caused a moderate but significant improvement $(<1.2$-fold) in frontal cortex PE and phosphatidylinositol (PI) but no changes in other PL classes. Addition of ARA/DHA to the formula did not lead to higher levels of ARA in the frontal cortex or hippocampus; on the contrary, in the latter the ARA level was lower in the supplemented group (42). Craig-Schmidt et al. reported increases in retinal phospholipid DHA for piglets supplemented with $1 \%$ wt ARA and $0.8 \%$ wt DHA. They found 1.3-fold higher ARA level in the retina phosphatidylcholine (PC) ARA but not in PE ARA after supplementation (43).

Artificially reared rats fed diets with $>2 \%$ wt ARA and $>2 \%$ wt DHA showed that the DHA content of forebrain phospholipids were significantly elevated after $3 \mathrm{wk}$ and $9 \mathrm{wk}$ of supplementation. The RBC DHA levels showed an average 2.3 -fold increase after $9 \mathrm{wk}$ in the different PL classes $(44,45)$. We also found a 2.3-fold greater level for this tissue in baboons. In rhesus macaque infants, the breast-fed animals had the highest level of plasma DHA even though the breast milk contained less than half the DHA concentration of the supplemented formula, which had 1\%wt ARA and $1 \% \mathrm{wt}$ DHA. At $4 \mathrm{wk}$ of age, the plasma DHA of the supplemented animals increased by 3.4 -fold and ARA by 1.6 -fold. These figures are very close to our 3.3-fold and 1.7-fold increases in the plasma levels for DHA and ARA, respectively, in premature baboons (46).

We examined the correlation between plasma and RBC ARA versus organ ARA levels. Other than one significant but weak correlation, our analysis shows that RBC or plasma ARA is not predictive of organ ARA concentrations. On the other hand, plasma and RBC DHA were predictive of group tissue DHA in all cases examined, as shown in Figs. $2 A-C$. Additionally, analysis accounting for group effects as categorical data show that all variability is explained by group effects, and that within a group, levels were uncorrelated. We conclude that that RBC and plasma DHA concentrations are useful proxies for brain, retina, and liver DHA levels, and that caution is warranted when comparing these levels over a small range.

\section{CONCLUSION}

In conclusion, our results indicate that unsupplemented formula caused a precipitous drop in DHA of brain and related tissues, and that formula supplemented with 0.3 energy\% DHA and 0.6 energy\% ARA prevented this drop in retina and liver. Retina and brain DHA concentrations are more resistant to dietary manipulation than liver or blood DHA, and tissue ARA levels are less sensitive than DHA to LCP supplementation and prematurity, and may decrease with supplementation. $\mathrm{RBC}$ and plasma total ARA is unresponsive to changes in tissue ARA and thus cannot be used as a proxy for tissue ARA. Finally, brain, retina, and liver DHA concentrations are significantly correlated to plasma and RBC levels, and these correlations were fully explained by group effects.

Acknowledgments. Formula and encapsulated LCP were the gift of Mead Johnson Nutritionals, Evansville, IN. The authors gratefully acknowledge Carolyn Tschanz for assistance with the manuscript.

\section{REFERENCES}

1. Neuringer M, Anderson GJ, Connor WE 1988 The essentiality of n-3 fatty acids for the development and function of the retina and brain. Annu Rev Nutr 8:517-541

2. Uauy R, Mena P, Rojas C 2000 Essential fatty acid metabolism in the micropremie. Clin Perinatol 27:71-93

3. Carlson SE, Cooke RJ, Rhodes PG, Peeples JM, Werkman SH, Tolley EA 1991 Long-term feeding of formulas high in linolenic acid and marine oil to very low birth weight infants: phospholipid fatty acids. Pediatr Res 30:404-412

4. Carlson SE, Werkman SH, Rhodes PG, Tolley EA 1993 Visual-acuity development in healthy preterm infants: effect of marine- oil supplementation. Am J Clin Nutr $58: 35-42$

5. Uauy R, Birch E, Birch D, Peirano P 1992 Visual and brain function measurements in studies of n-3 fatty acid requirements of infants. J Pediatr 120:S168-180

6. Carlson SE, Werkman SH, Peeples JM, Cooke RJ, Tolley EA 1993 Arachidonic acid status correlates with first year growth in preterm infants. Proc Natl Acad Sci USA 90:1073-1077

7. Koletzko B, Agostoni C, Carlson SE, Clandinin T, Hornstra G, Neuringer M, Uauy R, Yamashiro Y, Willatts P 2001 Long chain polyunsaturated fatty acids (LC-PUFA) and perinatal development. Acta Paediatr 90:460-464 
8. Gibson RA, Chen W, Makrides M 2001 Randomized trials with polyunsaturated fatty acid interventions in preterm and term infants: functional and clinical outcomes. Lipids 36:873-883

9. SanGiovanni JP, Parra-Cabrera S, Colditz GA, Berkey CS, Dwyer JT 2000 Meta-analysis of dietary essential fatty acids and long-chain polyunsaturated fatty acids as they relate to visual resolution acuity in healthy preterm infants Pediatrics 105:1292-1298

10. Koletzko B, Knoppke B, von Schenck U, Demmelmair H, Damli A 1999 Noninvasive assessment of essential fatty acid status in preterm infants by buccal mucosal cell phospholipid analysis. J Pediatr Gastroenterol Nutr 29:467-474

11. Hoffman DR, Birch EE, Birch DG, Uauy R 1999 Fatty acid profile of buccal cheek cell phospholipids as an index for dietary intake of docosahexaenoic acid in preterm infants. Lipids 34:337-342

12. Sampugna J, Light L, Enig MG, Jones DY, Judd JT, Lanza E 1988 Cheek cell fatty acids as indicators of dietary lipids in humans. Lipids 23:131-136

13. Hoffman DR, Uauy R 1992 Essentiality of dietary omega 3 fatty acids for premature infants: plasma and red blood cell fatty acid composition. Lipids 27:886-895

14. Clandinin MT, Van Aerde JE, Parrott A, Field CJ, Euler AR, Lien EL 1997 Assessment of the efficacious dose of arachidonic and docosahexaenoic acids in preterm infant formulas: fatty acid composition of erythrocyte membrane lipids. Pediatr Res 42:819-825

15. Vanderhoof J, Gross S, Hegyi T, Clandinin T, Porcelli P, DeCristofaro J, Rhodes T, Tsang R, Shattuck K, Cowett R, Adamkin D, McCarton C, Heird W, Hook-Morris B, Pereira G, Chan G, Van Aerde J, Boyle F, Pramuk K, Euler A, Lien EL 1999 Evaluation of a long-chain polyunsaturated fatty acid supplemented formula on growth, tolerance, and plasma lipids in preterm infants up to 48 weeks postconceptional age. J Pediatr Gastroenterol Nutr 29:318-326

16. Vanderhoof J, Gross S, Hegyi T 2000 A multicenter long-term safety and efficacy trial of preterm formula supplemented with long-chain polyunsaturated fatty acids. J Pediatr Gastroenterol Nutr 31:121-127

17. Field CJ, Thomson CA, Van Aerde JE, Parrott A, Euler A, Lien E, Clandinin MT 2000 Lower proportion of CD45R0 + cells and deficient interleukin-10 production by formula-fed infants, compared with human-fed, is corrected with supplementation of long-chain polyunsaturated fatty acids. J Pediatr Gastroenterol Nutr 31:291-299

18. Makrides M, Neumann MA, Byard RW, Simmer K, Gibson RA 1994 Fatty acid composition of brain, retina, and erythrocytes in breast- and formula-fed infants. Am J Clin Nutr 60:189-194

19. Farquharson J, Cockburn F, Patrick WA, Jamieson EC, Logan RW 1992 Infan cerebral cortex phospholipid fatty-acid composition and diet. Lancet 340:810-813

20. Byard RW, Makrides M, Need M, Neumann MA, Gibson RA 1995 Sudden infant death syndrome: effect of breast and formula feeding on frontal cortex and brainstem lipid composition. J Paediatr Child Health 31:14-16

21. Jamieson EC, Farquharson J, Logan RW, Howatson AG, Patrick WJ, Weaver LT, Cockburn F 1999 Infant cerebellar gray and white matter fatty acids in relation to age and diet. Lipids 34:1065-1071

22. Walther FJ, den Ouden AL, Verloove-Vanhorick SP 2000 Looking back in time: outcome of a national cohort of very preterm infants born in The Netherlands in 1983. Early Hum Dev 59:175-191

23. Hack M, Flannery DJ, Schluchter M, Cartar L, Borawski E, Klein N 2002 Outcomes in young adulthood for very-low-birth-weight infants. N Engl J Med 346:149-157

24. Bhutta AT, Cleves MA, Casey PH, Cradock MM, Anand KJ 2002 Cognitive and Behavioral Outcomes of School-Aged Children Who Were Born Preterm: A Metaanalysis. JAMA 288:728-737

25. Crawford MA 1993 The role of essential fatty acids in neural development: implications for perinatal nutrition. Am J Clin Nutr 575:703S-710S

26. Salem N, Jr., Wegher B, Mena P, Uauy R 1996 Arachidonic and docosahexaenoic acids are biosynthesized from their 18-carbon precursors in human infants. Proc Natl Acad Sci USA 93:49-54

27. Carnielli VP, Wattimena DJ, Luijendijk IH, Boerlage A, Degenhart HJ, Sauer PJ 1996 The very low birth weight premature infant is capable of synthesizing arachidonic and docosahexaenoic acids from linoleic and linolenic acids. Pediatr Res 40:169-174
28. Su HM, Bernardo L, Mirmiran M, Ma XH, Nathanielsz PW, Brenna JT 1999 Dietary $18: 3 n-3$ and $22: 6 n-3$ as sources of $22: 6 n-3$ accretion in neonatal baboon brain and associated organs. Lipids 34 Suppl:S347-350

29. Farine D, MacCarter GD, Timor-Tritch IE, Yeh MN, Stark RI 1988 Real-time ultrasonic evaluation of the baboon pregnancy: biometric measurements. J Med Primatol 17:215-221

30. Sheaff RC, Su H-M, Keswick LA, Brenna JT 1995 Conversion of $\alpha$-linolenate to docosahexaenoate is not depressed by high dietary levels of linoleate in young rats: tracer evidence using high precision mass spectrometry. J Lipid Res 36:9981008

31. Bligh E, Dyer W 1959 A rapid method of total lipid extraction and purification. Can J Biochem Physiol 37:911-917

32. Innis SM, Hrboticky N, Foote KD 1989 Essential fatty acid metabolism in infants. Nutrition 5:256-258

33. Lauritzen L, Hansen HS, Jorgensen MH, Michaelsen KF 2001 The essentiality of long chain n-3 fatty acids in relation to development and function of the brain and retina. Prog Lipid Res 40:1-94

34. Birch DG, Birch EE, Hoffman DR, Uauy RD 1992 Retinal development in very-lowbirth-weight infants fed diets differing in omega-3 fatty acids. Invest Ophthalmol Vis Sci 33:2365-2376

35. Jacobs NJ, van Zoeren-Grobben D, Drejer GF, Bindels JG, Berger HM 1996 Influence of long chain unsaturated fatty acids in formula feeds on lipid peroxidation and antioxidants in preterm infants. Pediatr Res 40:680-686

36. Garn SM, Greaney GR, Young RW 1956 Fat thickness and growth process during infancy. Hum Biol 28:232-250

37. Ulijaszek SJ 2002 Comparative energetics of primate fetal growth. Am J Human Biol 14:603-608

38. Cunnane SC, Francescutti V, Brenna JT, Crawford MA 2000 Breast-fed infants achieve a higher rate of brain and whole body docosahexaenoate accumulation than formula-fed infants not consuming dietary docosahexaenoate. Lipids 35:105-111

39. Abedin L, Lien EL, Vingrys AJ, Sinclair AJ 1999 The effects of dietary alphalinolenic acid compared with docosahexaenoic acid on brain, retina, liver, and heart in the guinea pig. Lipids 34:475-482

40. Alessandri JM, Goustard B, Guesnet P, Durand G 1998 Docosahexaenoic acid concentrations in retinal phospholipids of piglets fed an infant formula enriched with long-chain polyunsaturated fatty acids: effects of egg phospholipids and fish oils with different ratios of eicosapentaenoic acid to docosahexaenoic acid. Am J Clin Nutr 67:377-385

41. Goustard-Langelier B, Guesnet P, Durand G, Antoine JM, Alessandri JM 1999 n-3 and n-6 fatty acid enrichment by dietary fish oil and phospholipid sources in brain cortical areas and nonneural tissues of formula-fed piglets. Lipids 34:5-16

42. de la Presa Owens S, Innis SM 2000 Diverse, region-specific effects of addition of arachidonic and docosahexanoic acids to formula with low or adequate linoleic and alpha-linolenic acids on piglet brain monoaminergic neurotransmitters Pediatr Res 48:125-130

43. Craig-Schmidt MC, Stieh KE, Lien EL 1996 Retinal fatty acids of piglets fed docosahexaenoic and arachidonic acids from microbial sources. Lipids 31:53-59

44. Wainwright PE, Xing HC, Ward GR, Huang YS, Bobik E, Auestad N, Montalto M 1999 Water maze performance is unaffected in artificially reared rats fed diets supplemented with arachidonic acid and docosahexaenoic acid. J Nutr 129:1079-1089

45. Ward GR, Huang YS, Bobik E, Xing HC, Mutsaers L, Auestad N, Montalto M, Wainwright P 1998 Long-chain polyunsaturated fatty acid levels in formulae influence deposition of docosahexaenoic acid and arachidonic acid in brain and red blood cells of artificially reared neonatal rats. J Nutr 128:2473-2487

46. Champoux M, Hibbeln JR, Shannon C, Majchrzak S, Suomi SJ, Salem N, Jr, Higley JD 2002 Fatty acid formula supplementation and neuromotor development in rhesus monkey neonates. Pediatr Res 51:273-281 